\title{
RESIDUAL LEVELS OF ORGANOCHLORINE PESTICIDES AND HEAVY METALS IN SHELLFISH FROM EGYPT WITH ASSESSMENT OF HEALTH RISKS
}

\author{
Taghred M. Saber ${ }^{1 *}$, Mariam H. E. Khedr², Wageh Sobhy Darwish ${ }^{3}$ \\ ${ }^{1}$ Forensic Medicine and Toxicology Department, ${ }^{2}$ Department of Veterinary Public Health, ${ }^{3}$ Food Control Department, Faculty of Veterinary \\ Medicine, Zagazig University, Zagazig 44519, Egypt \\ *Corresponding author, Email: taghred_saber@yahoo.com
}

\begin{abstract}
This study investigated the levels of organochlorine pesticides (OCPs) and heavy metal residues in shellfish (shrimp, oyster and crab) collected from three Egyptian governorates (Ismailia, Damietta and Alexandria). Levels of 12 OCPs such as hexachlorocyclohexanes $(\mathrm{HCHs})$, aldrin, endrin and dichlorodiphenyltrichloroethanes (DDTs) residues were determined. The dominant detected OCPs were B-HCH, p,p-DDE and endrin. The contamination pattern of OCPs was in the order of other OCPs (HCB, heptachlor, heptachlor-epoxide, aldrin, endrin and $\gamma$ chlordane) $>\mathrm{HCHs}>$ DDTs. Residual levels of some heavy metals and trace elements were also estimated. The highest residual levels of OCPs and heavy metals were found in oysters collected from Damietta. The health risk assessment was determined by calculating hazard ratio and hazard index. Concentrations of OCPs and heavy metals in examined shellfish were below the maximum residual level set by United States Food and Drug Administration and FAO. Therefore, shellfish collected from these studied sites could be considered safe for human consumption.
\end{abstract}

Key words: organochlorine pesticides; heavy metals; shellfish; health risks; Egypt

\section{Introduction}

Organochlorine pesticides (OCPs) are considered as persistent pollutants all over the world due to their persistence in the environment; bioaccumulation; their magnification ability in food chain and induction of toxicity for human and wildlife (1). These pollutants enter the aquatic environment and could be transported into food chains, then accumulated in the aquatic organisms. Lastly, OCPs might reach human via consumption of fish and fish products, drinking water and agriculture

Received: 19 May 2017

Accepted for publication: 21 November 2017 foods (2). In Egypt since 1980s, several OCPs and their metabolites were found with different levels in fish where the OCPs use has been banned $(3,4)$.

Heavy metals, as major environmental contaminants, has detrimental effects on the aquatic organisms and human (5).Consequently, these metals reach the aquatic ecosystem through the natural and anthropogenic sources and causing serious threats due to their toxicity, bioaccumulations in food chain and nonbiodegradable nature in the aquatic environments (6). The levels of heavy metals were elevated in natural water because of increasing the industrial and agricultural activities (7). Metals such as copper, chromium, zinc and nickel and iron are 
essential trace elements playing a vital role in the biological systems, whereas non-essential metals including lead, cadmium, arsenic and mercury are bioaccumlated in tissues leading to intoxication, damage of cells and tissues, reduced fertility, cell death and organ dysfunctions $(8,9)$.

Fish and shellfish are delicious food that support humans with high quality protein, various minerals, polyunsaturated fatty acids and vitamins. In addition, fish and shellfish are considered as one of the valuable bioindicators for pollution in the aquatic habitats as a result of their lower detoxification enzymes (e.g. monooxygenases) than those in mammals and thereby allowing a higher bioaccumulation for toxicants $(10,11)$. Besides, these metals will provide more reliable information on the impact on public health arising from seafood consumption (12). Information available about OCPs and heavy metal residues in shellfish in Egypt is very limited. This study aimed to investigate the levels of OCPs and heavy metal residues in three shellfish species (shrimp, oyster and crab) collected from Ismailia, Damietta and Alexandria Governorates, Egypt, and to assess the potential risks on the public health arising from shellfish consumption.

\section{Materials and methods}

\section{Study area and sample collection}

Ismailia is a province situated near the Delta with low industrial and agricultural activities, while Damietta is close to Nile Delta, where agricultural activities and industries are predominant. Alexandria is located in the North West of Delta extending for about $75 \mathrm{~km}$ along the Egyptian Mediterranean coast with medium industrial and agricultural activities (Fig. 1). Sixty-three samples of three shellfish species (shrimp, crab and oyster) were collected from fish markets at Ismailia, Damietta and Alexandria Governorates at Egypt during March to June 2015. The collection scheme was twenty-one samples per each governorate (as divided seven shellfish samples per each species).

The collected shellfish species; including white shrimp (Penaeus setiferus), blue crab (Callinectes sapidus) and oyster (Crassostrea gigas); were stored at $-20^{\circ} \mathrm{C}$ until analysis. The residues of OCPs and heavy metals were analyzed in the edible portions of shellfish samples.

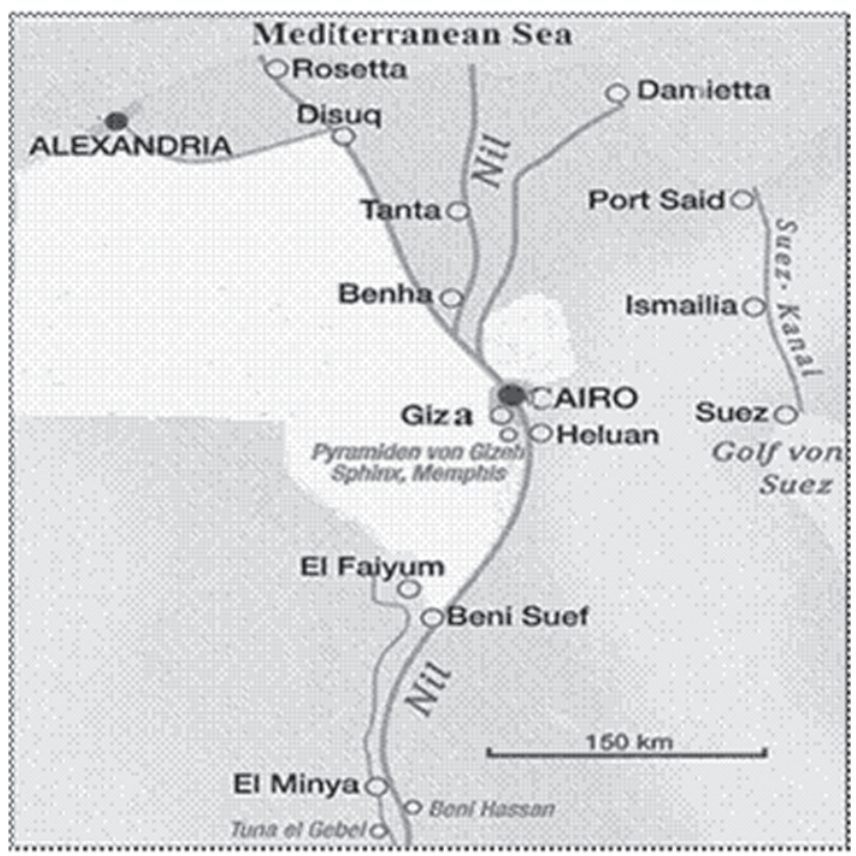

Figure 1: Location of sampling sites; Ismailia, Damietta and Alexandria

\section{Analysis of OCPs residues}

The processing and analysis of shellfish samples were carried out according to the previously described method by Yohannes et al. (13). In brief, approximately 10 gm of each edible shellfish sample was homogenized with anhydrous sodium sulfate, and then extracted with $150 \mathrm{~mL}$ hexane: acetone $(3: 1, \mathrm{v} / \mathrm{v})$ for $6 \mathrm{~h}$ in a Soxhlet S306AK Automatic Extractor System (Gerhardt, Germany). Firstly, the extract was concentrated with a rotary evaporator to about $2 \mathrm{~mL}$, and then secondly was diluted with hexane to $10 \mathrm{~mL}$. An aliquot from the extract was cleaned-up after the evaporation of solvent on the glass column that is packed with $6 \mathrm{gm}$ of activated florisil, then eluted with $80 \mathrm{~mL}$ hexane containing a diethyl ether of $25 \%$. The rotary evaporator concentrated the elute, then was dried using gentle nitrogen flow. The extract was redissolved in n-decane $(100 \mu \mathrm{L})$, then transferred to gas chromatography (GC) vials for the analysis process.

The analysis of twelve OCPs including hexachlorocyclohexanes (HCHs; $\mathrm{a}-, \quad \beta-$ and $\gamma-\mathrm{HCH})$, hexachlorobenzene (HCB), heptachlor, heptachlor-epoxide, aldrin, endrin, $\gamma$ chlordane, and dichlorodiphenyltrichloroethanes (DDTs; p,pDDE, p, p-DDD and p, p-DDT) was achieved with a gas-chromatography equipped with a detector 
of Ni electron capture (GCECD: Shimadzu GC2014,Kyoto, Japan). An ENV8MS capillary column with the splitless injection was utilized to separate OCPs. One $\mu 1$ of each sample was injected. The temperature of GC oven was initially set at $100{ }^{\circ} \mathrm{C}$ for $1 \mathrm{~min}$, then raised up to $180^{\circ} \mathrm{C}$ at $20^{\circ} \mathrm{C} / \mathrm{min}$, and then to $260{ }^{\circ} \mathrm{C}$ at $4{ }^{\circ} \mathrm{C} / \mathrm{min}$, finally was held for $5 \mathrm{~min}$. The temperature of injector was 250 ${ }^{\circ} \mathrm{C}$, while that of detector was $310^{\circ} \mathrm{C}$. Helium was used as a carrier gas at a flow rate $(1.0 \mathrm{~mL} / \mathrm{min})$, while nitrogen (as a make -up gas) was at a flow rate of $45 \mathrm{ml} / \mathrm{min}$.

\section{Heavy metal analysis}

Fish samples were digested according to the method of Finerty et al. (14). In brief, one gm of each sample was mixed with $10 \mathrm{~mL} \mathrm{3:2} \mathrm{nitric}$ acid $(65 \% \mathrm{v} / \mathrm{v})$ : Perchloric acid $(70 \% \mathrm{v} / \mathrm{v})$. The mixture was allowed to digest overnight at room temperature, then it was heated for three $h$ in a water bath at $70{ }^{\circ} \mathrm{C}$ with whirling at intervals of $30 \mathrm{~min}$ for the accuracy of complete digestion. After cooling, the digested shellfish samples were diluted with $20 \mathrm{~mL}$ de-ionized water then filtered through a Whatman filter paper (No. 42). Similar procedure was applied for the blank. For determination of $\mathrm{Pb}, \mathrm{Cd}, \mathrm{As}, \mathrm{Cu}, \mathrm{Cr}, \mathrm{Zn}, \mathrm{Ni}$ and $\mathrm{Fe}$ residue levels in shellfish samples, the analysis of filtrate was performed using Buck V210GP atomic absorption spectrophotometer (Buck Scientific Instrument Manufacturing Co., Norwalk, CT, USA) using lambs of hollow cathode, equipped with air-acetylene flame. While, Hg was measured a cold vapor atomic absorption spectrophotometer (Varian VGA-77; Agilent Technologies, Santa Clara, CA, USA).

\section{Quality assurance and quality control}

The OCPs were identified by comparing their retention time with reference to the corresponding standard. The quality control was conducted by analysis of procedural blanks and spiked blanks for each 7 samples. The detection limits based on 3:1 signal to noise ratio $(\mathrm{S} / \mathrm{N})$ were between 0.05 and $0.1 \mathrm{ng} / \mathrm{g}$ for all analyzed OCPs. The recovery rate of OCPs was ranged from $80-102 \%$ and the results have not been corrected for recoveries.

For testing the accuracy and validity of analytical procedures of heavy metals, the reference material; DORM-3 (Fish protein, the National Research Council, Canada) was used. Replicate analysis of this reference material demonstrated good accuracy with recovery rates ranged from $80 \%$ to $115 \%$. The detection limits for heavy metals were $0.1 \mu \mathrm{g} / \mathrm{g}$ for lead $(\mathrm{Pb}), 0.005$ $\mu \mathrm{g} / \mathrm{g}$ for cadmium (Cd), $0.02 \mu \mathrm{g} / \mathrm{g}$ for arsenic (As), $0.2 \mu \mathrm{g} / \mathrm{g}$ for mercury $(\mathrm{Hg}), 0.02 \mu \mathrm{g} / \mathrm{g}$ for copper $(\mathrm{Cu}), 0.05 \mu \mathrm{g} / \mathrm{g}$ for chromium $(\mathrm{Cr}), 0,005 \mu \mathrm{g} / \mathrm{g}$ for zinc $(\mathrm{Zn}), 0.01 \mu \mathrm{g} / \mathrm{g}$ for nickel $(\mathrm{Ni})$ and $0.005 \mu \mathrm{g} / \mathrm{g}$ for iron $(\mathrm{Fe})$.

\section{Estimated daily intake (EDI)}

The EDI was calculated on the basis of incorporation of data from heavy metals analysis, rates of fish consumption, and body weight of Egyptian adults. EDI $(\mu \mathrm{g} / \mathrm{kg} /$ day $)$ for heavy metals was calculated by using the following equation which is explained by the Human Health Evaluation Manual (US Environmental Protection Agency, EPA) (15):

$$
\mathrm{EDI}=\frac{\mathrm{C}_{\mathrm{m}} * \mathrm{~F}_{\mathrm{IR}}}{\mathrm{BW}}
$$

Where $\mathrm{C}_{\mathrm{m}}$ is the metal concentration in the sample (mg/kg wet weight); $F_{I R}$ is the food (fish) ingestion rate in Egypt, which was determined at $48.57 \mathrm{~g} /$ day (16); BW is the body weight of Egyptian adults, which was determined at $70 \mathrm{~kg}$.

\section{Health risk assessment}

The US EPA (15) quantitatively evaluates the health risks for humans in terms of non-cancer and cancer risks. This study was designed to quantify the non-cancer risks imposed on the three locations under the study at Egypt, by consumption of metal contained fish. The assessment of risks followed the guidelines adopted by the US EPA (2007)(15). For the non-cancer risks, EDI was compared with the recommended reference doses (RfD) (4E03, 1E03, 3E04, 5E04, 0.3, 3E03, 0.3, $2 \mathrm{E} 02 \mathrm{mg} / \mathrm{kg} / \mathrm{d}$ for $\mathrm{Pb}, \mathrm{Cd}, \mathrm{As}, \mathrm{Hg}, \mathrm{Cu}, \mathrm{Cr}, \mathrm{Zn}$, $\mathrm{Ni}$; respectively) (15), as was illustrated in the following equation:

$$
\operatorname{Hazard} \text { Ratio }(\mathrm{HR})=\frac{\text { EDI }}{\mathrm{RfD}}
$$


The hazard ratios (HRs) could be added together to estimate a hazard index (HI) to evaluate the risk of mixed contaminants. HI was measured using the following equation:

$$
\mathrm{HI}=\sum \mathrm{HR} i
$$

Where $i$ represent each metal. HR and/or HI of $>1$ demonstrates that there is a potential risk for human health, while a result of $\leq 1$ shows no risk for detrimental health effects.

\section{Statistical analysis}

The obtained data were expressed as the mean \pm standard error (SE). The statistical analysis was performed using two-way analysis of variance (ANOVA) to evaluate the statistical differences in the concentrations of heavy metals between different shellfish species and localities followed by the post-hoc Duncan's test. This was carried out using IBM SPSS Statistics computer software (version 21). All the statistical analyses were done at the significance level of $0.05(\mathrm{P}<0.05)$.

\section{Results and discussion}

\section{Concentration of OCPs}

In this study, the residual levels of OCPs in shellfish on wet weight basis (ng/g ww) were dominated by other OCPs (HCB, heptachlor, heptachlor-epoxide, aldrin, endrin and $\gamma$ chlordane) followed by $\mathrm{HCHs}(\mathrm{a}-, \beta-$ and $\gamma-\mathrm{HCH})$ then DDTs (p,p-DDE, p, p-DDD and p, p-DDT). OCPs concentrations were in the range of ND-63.53 ng/g ww (Table 1). The maximum concentration of OCPs was found in oysters collected from Damietta. This highest OCPs residual level in oysters could be due to their feeding habits, where these molluscan shellfish are filter feeders, and thus, they could concentrate these pollutants at higher levels than others found in the water environment (17). In addition, the highest residual levels of OCPs in shellfish from Damietta may be related to the increase in the agricultural and industrial activities.

\section{$\mathrm{HCHs}$}

Shellfish revealed total $\mathrm{HCHs}$ within the range of ND-12.27 ng/g ww (Table 1). This concentration level was nearly similar to that reported in shellfish from Qiantang River, China (18). However, higher HCHs levels (16.20- 183.40 $\mathrm{ng} / \mathrm{g}$ ww) were detected in mussels from the Red Sea (19). The highest concentration of total HCHs was recovered in oysters at Damietta. The $\beta-\mathrm{HCH}$ was the predominant isomer in $\mathrm{HCHs}$ for all shellfish followed by $\gamma-\mathrm{HCH}$ then a-HCH. Similar finding was cited in shellfish from Qiantang River, China (18). This result might be attributed to the stability, environmental existence, resistance for microbial degradation, long half-life with vapor pressure and low solubility of $\beta-\mathrm{HCH}$ (20). However, some studies reported that a-HCH was the predominant HCHs isomer in fish $(10,21)$.

\section{DDTs}

Total DDTs concentrations in examined shellfish had a range from ND to $8.64 \mathrm{ng} / \mathrm{g}$ ww (Table 1). Although, higher concentrations of total DDTs were recorded in shellfish from Qiantang River, China (18) and in mussels from the Red Sea (19). The highest level for total DDTs was also detected in oysters from Damietta. Moreover, these results may be accounted for the high chemical stability, hydrophobicity of p,p- DDE, its long half-life and persistence in the biotic and abiotic components of aquatic ecosystem (22).The high levels of DDE and low DDT concentrations in shellfish could indicate that the DDT had not been recently used in the agricultural activities after its ban (23).

\section{Other OCPs}

Total other OCPs concentrations in shellfish ranged from ND to $42.62 \mathrm{ng} / \mathrm{g}$ ww. Endrin was predominant among other OCPs with the range of ND-29.00 ng/g ww. Oysters collected from Damietta showed the highest residual levels of total other OCPs (Table 1). The residual levels of OCPs detected in fish samples were below the maximum residual limit (MRL) set by United States Food and Drug Administration (US FDA) (24) and Food and Agriculture Organization (FAO)(25) (Table 1). 
Thus, their human health risk assessment was not assessed in this study. Concerning the Commission Regulation of European community (EC) No 396(26) and amendments $(27,28,29)$, we found that MRLs of pesticide residues in fish not applicable until the individual products are identified and listed. OCPs residues in studied shellfish may be attributed to unauthorized use of pesticides in the agriculture or as a result of marine water contamination

\section{Heavy metal concentrations}

The concentration of heavy metals was expressed as $\mu \mathrm{g} / \mathrm{g}$ ww in shellfish samples (Tables 2 and 3). There was no a significant difference in the toxic metal levels between different species from the same locality. On the other hand, the mean concentrations of trace elements were significantly $(\mathrm{P}<0.05)$ different among different species. Moreover, edible portions of oysters harboured the highest residual levels of $\mathrm{Cu}$ and Ni. This was supported by Rainbow (17), who declared that the highest trace elements levels in oysters might be attributed to their feeding habits. Furthermore, there was asignificant difference in heavy metal concentrations among different localities. Our data depicted that the highest heavy metal concentrations were noticed in Damietta due to an increase in industrial and agricultural activities.

Lead $(\mathrm{Pb})$ is a toxic heavy metal causing retardation in growth, anemia and neuronal defects in children. In addition, $\mathrm{Pb}$ chronic posioning could induce toxicity in different organs such as liver, kidney and brain (30).The present study showed a range for $\mathrm{pb}$ concentrations in shellfish (0.84 to $1.63 \mu \mathrm{g} / \mathrm{g}$ ww) with a mean value of $1.19 \mu \mathrm{g} / \mathrm{g}$ ww (Table 2). The highest $\mathrm{Pb}$ level was observed in oysters from Damietta, while the lowest concentration was found in crabs from Ismailia. $\mathrm{Pb}$ levels in this study were within the range (0.67-0.99 $\mu \mathrm{g} / \mathrm{g} \mathrm{ww})$ recorded in mussels from Alexandria, Egypt (31). Conversely, it was higher than that reported (ND-0.55 $\mu \mathrm{g} / \mathrm{g}$ ww) in fish from Palestine (32). It is surprising, $\mathrm{Pb}$ levels in this study exceeded the maximum permissible limit (MPL) $(0.5 \mu \mathrm{g} / \mathrm{g} w \mathrm{w})$ recommended by FAO (25) in fish and Commission Regulation (EC) No 1881(33) in crustacean fish. Although, these $\mathrm{Pb}$ levels were lower than MPL proposed by US FDA (24) in shellfish and Commission Regulation (EC) No 1881(33) in oysters .
Acute cadmium (Cd) intoxication in humans is manifested by nausea, vomiting, diarrhea, pain in abdomen and shock. While, the Cd chronic toxicity causes dysfunction of renal tubules and appearance of Itai-itai disease (34). The $\mathrm{Cd}$ residual concentrations in shellfish ranged from $0.21-0.55 \mu \mathrm{g} / \mathrm{g}$ ww with a mean value of 0.38 $\mu \mathrm{g} / \mathrm{g}$ ww (Table 2). The highest concentration was detected in oysters from Damietta; whereas the lowest level was found in crabs from Ismailia. In the present study, Cd concentrations were nearly close to levels (0.16-0.65 $\mu \mathrm{g} / \mathrm{g} w \mathrm{w})$ that reported in fish, Giza, Egypt (35). However, lower levels (ND$0.09 \mu \mathrm{g} / \mathrm{g} \mathrm{ww}$ ) were detected in fish from Palestine (32). Cd levels in the present study were below the MPL adopted by FAO (25) $(0.5 \mu \mathrm{g} / \mathrm{g} w w)$ in fish, US FDA (24) and Commission Regulation (EC) No 1881(33) in shellfish.

Arsenic (As) is a toxic element that has carcinogenic effects and non-carcinogenic effects including genotoxicity and immunotoxicity (36, 37). The range of As levels in shellfish was 0.81 to $1.45 \mu \mathrm{g} / \mathrm{g}$ ww with an average concentration of $1.13 \mu \mathrm{g} / \mathrm{g}$ ww (Table 2). It was clear that shellfish collected from Damietta showed the highest As residual levels. However, lower mean concentrations of As were recovered in shellfish from Ismailia. On the contrary, the residual As levels in this study were lower than those reported in fish from New Jersey (38). However, it was higher than those detected in seafood from Mumbai, India (39). In addition, As levels in this study were lower than the MPL for shellfish set by US FDA (24).

Mercury $(\mathrm{Hg})$ is a highly toxic element causing different adverse health effects that include neurologigal, immune, renal and developmental disorders (40). The concentrations of $\mathrm{Hg}$ in shellfish were varied from 0.53 to $1.16 \mu \mathrm{g} / \mathrm{g}$ ww with a mean value of $0.83 \mu \mathrm{g} / \mathrm{g}$ ww (Table 2$)$. The highest $\mathrm{Hg}$ levels were found in shellfish from Damietta, while the lowest concentrations were detected in the collected samples from Ismailia. The observed values of $\mathrm{Hg}$ in shellfish were higher than those found in fish from Mumbai Harbor, India (0.01-0.23 $\mu \mathrm{g} / \mathrm{g} w \mathrm{w}) \quad$ (41).The levels of $\mathrm{Hg}$ in the present study were below MPL of $0.5-1 \mu \mathrm{g} / \mathrm{g}$ ww $(33,42)$ except $\mathrm{Hg}$ concentrations in oysters from Damietta and Alexandria.

The levels of $\mathrm{Cu}$ in shellfish was ranged between 1.13 and $5.72 \mu \mathrm{g} / \mathrm{g}$ ww with an average value of $3.33 \mu \mathrm{g} / \mathrm{g}$ ww (Table 3).The maximum 


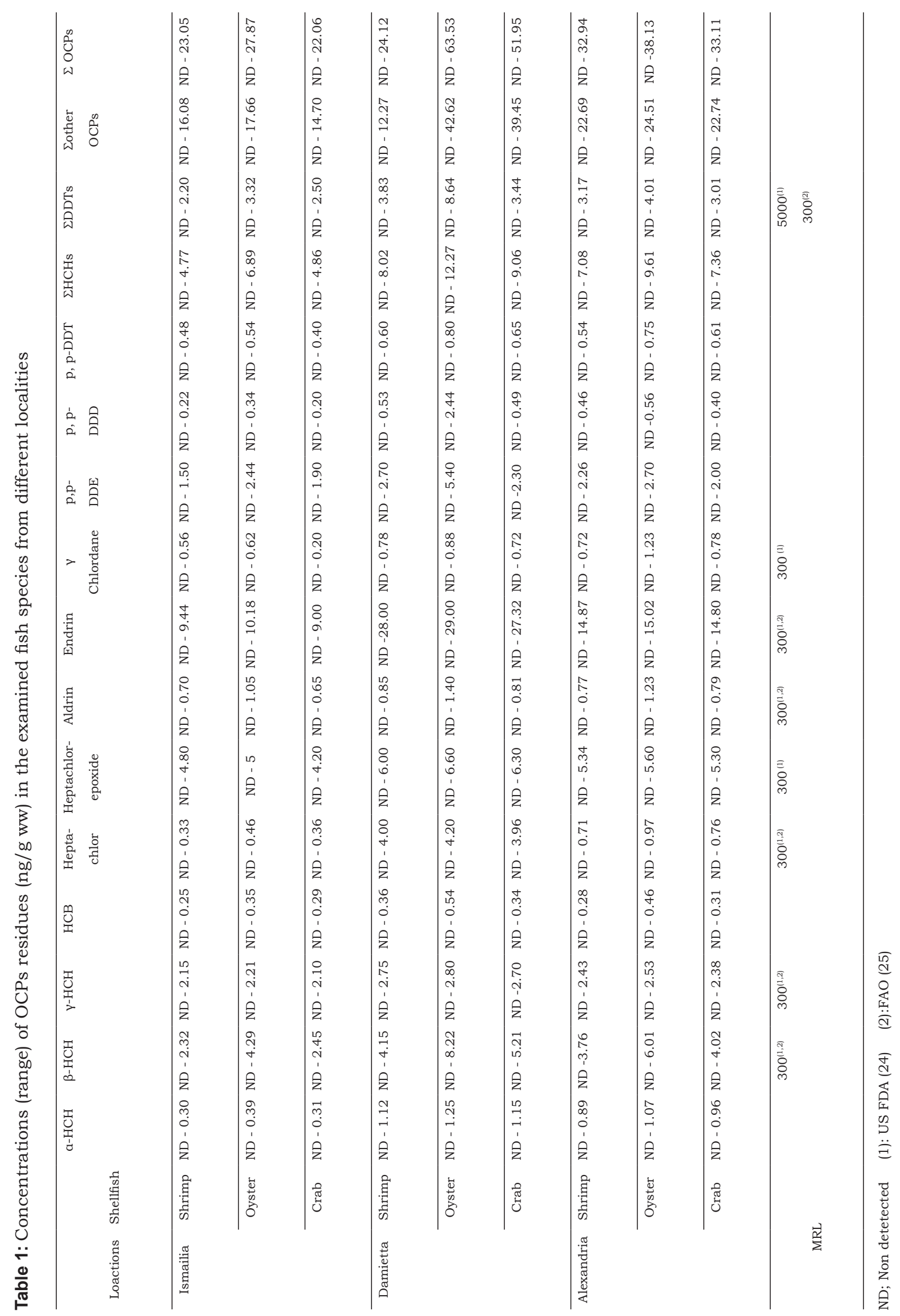




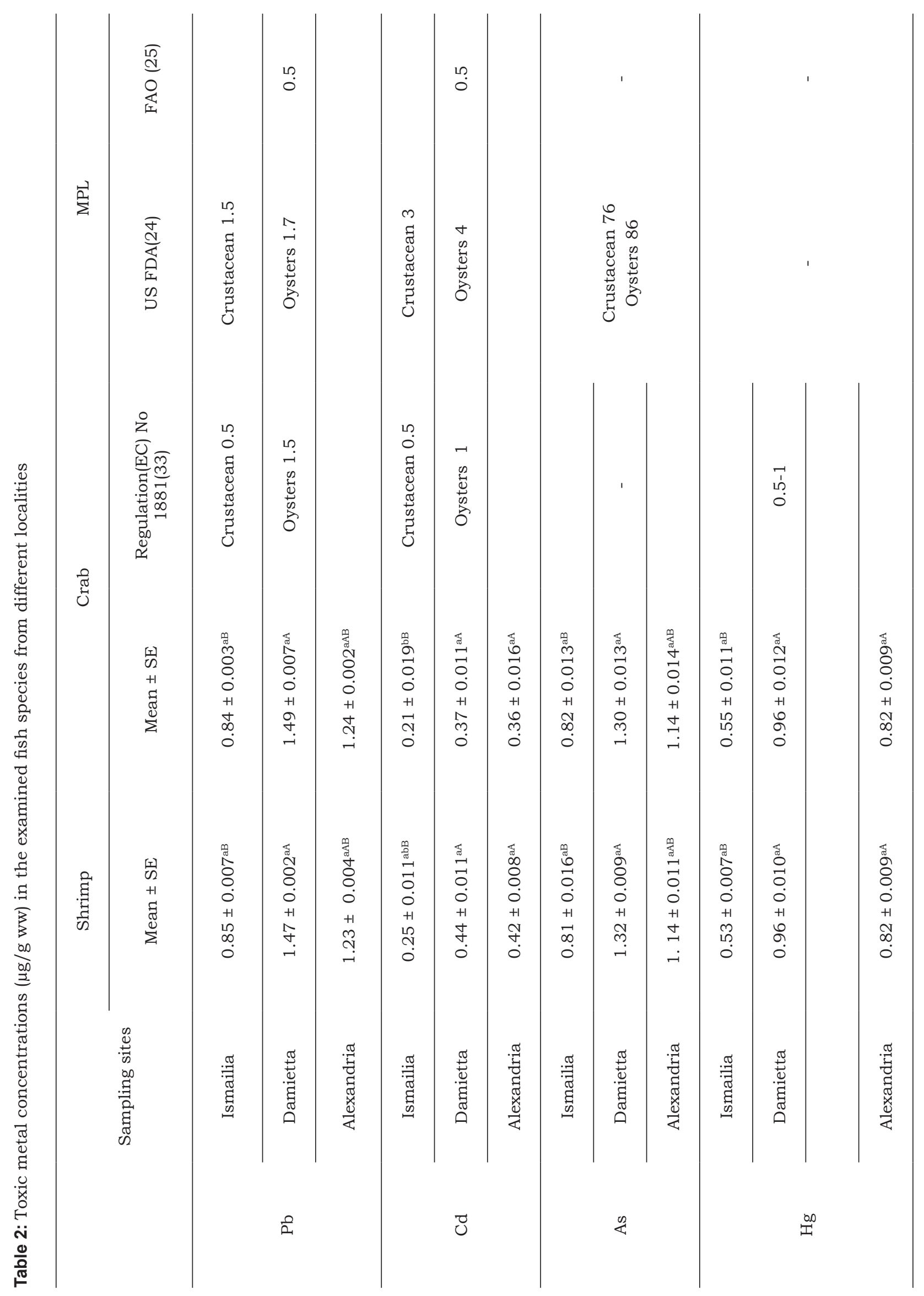


Table 3: Trace element concentrations ( $\mu \mathrm{g} / \mathrm{g} w \mathrm{w})$ in the examined fish species from different localities.

\begin{tabular}{|c|c|c|c|c|c|c|}
\hline & \multirow{2}{*}{$\begin{array}{l}\text { Sampling } \\
\text { sites }\end{array}$} & \multirow{2}{*}{$\frac{\text { Shrimp }}{\text { Mean } \pm \mathrm{SE}}$} & \multirow{2}{*}{$\frac{\text { Oyster }}{\text { Mean } \pm \mathrm{SE}}$} & \multirow{2}{*}{$\frac{\mathrm{Crab}}{\mathrm{Mean} \pm \mathrm{SE}}$} & \multicolumn{2}{|l|}{ MPL } \\
\hline & & & & & US FDA (24) & $\begin{array}{l}\text { FAO } \\
(25)\end{array}$ \\
\hline \multirow{3}{*}{$\mathrm{Cu}$} & Ismailia & $1.13 \pm 0.02^{\mathrm{cC}}$ & $2.44 \pm 0.06^{\mathrm{aC}}$ & $1.86 \pm 0.02^{\mathrm{bB}}$ & \multirow{3}{*}{-} & \multirow{3}{*}{30} \\
\hline & Damietta & $4.75 \pm 0.10^{\mathrm{aA}}$ & $5.72 \pm 0.08^{\mathrm{aA}}$ & $4.56 \pm 0.06^{\mathrm{aA}}$ & & \\
\hline & Alexandria & $3.14 \pm 0.02^{\mathrm{bB}}$ & $4.41 \pm 0.06^{\mathrm{aB}}$ & $1.97 \pm 0.03^{\mathrm{cB}}$ & & \\
\hline \multirow{3}{*}{$\mathrm{Cr}$} & Ismailia & $0.84 \pm 0.01^{\mathrm{aA}}$ & $1.02 \pm 0.01^{\mathrm{aA}}$ & $0.86 \pm 0.01^{\mathrm{aA}}$ & \multirow{3}{*}{$\begin{array}{c}\text { crustacean } 12 \\
\text { oysters } 13\end{array}$} & \multirow{3}{*}{-} \\
\hline & Damietta & $1.18 \pm 0.01^{\mathrm{aA}}$ & $1.37 \pm 0.02^{\mathrm{aA}}$ & $1.17 \pm 0.01^{\mathrm{aA}}$ & & \\
\hline & Alexandria & $0.96 \pm 0.10^{\mathrm{aA}}$ & $1.18 \pm 0.01^{\mathrm{aA}}$ & $1.06 \pm 0.01^{\mathrm{aA}}$ & & \\
\hline \multirow{3}{*}{$\mathrm{Zn}$} & Ismailia & $11.25 \pm 0.01^{\mathrm{aB}}$ & $13.33 \pm 0.01^{\mathrm{ac}}$ & $11.71 \pm 0.16^{\mathrm{aB}}$ & \multirow{3}{*}{-} & \multirow{3}{*}{40} \\
\hline & Damietta & $19.19 \pm 0.04^{\mathrm{abA}}$ & $22.19 \pm 0.08^{\mathrm{aA}}$ & $15.94 \pm 2.27^{\mathrm{bAB}}$ & & \\
\hline & Alexandria & $17.06 \pm 0.03^{\mathrm{aAB}}$ & $18.17 \pm 0.05^{\mathrm{aB}}$ & $17.18 \pm 0.03^{\mathrm{aA}}$ & & \\
\hline \multirow{3}{*}{$\mathrm{Ni}$} & Ismailia & $0.15 \pm 0.01^{\mathrm{bc}}$ & $0.25 \pm 0.02^{\mathrm{ac}}$ & $0.17 \pm 0.01^{\mathrm{bc}}$ & \multirow{3}{*}{$\begin{array}{c}\text { crustacean } 70 \\
\text { oysters } 80\end{array}$} & \multirow{3}{*}{-} \\
\hline & Damietta & $0.52 \pm 0.01^{\mathrm{cA}}$ & $1.30 \pm 0.01^{\mathrm{aA}}$ & $0.72 \pm 0.01^{\mathrm{bA}}$ & & \\
\hline & Alexandria & $0.34 \pm 0.01^{\mathrm{bB}}$ & $0.55 \pm 0.03^{\mathrm{aB}}$ & $0.44 \pm 0.01^{\mathrm{abB}}$ & & \\
\hline \multirow{3}{*}{$\mathrm{Fe}$} & Ismailia & $34.49 \pm 1.01^{\mathrm{bB}}$ & $46.17 \pm 0.94^{\mathrm{aB}}$ & $34.89 \pm 0.86^{\mathrm{bB}}$ & \multirow{3}{*}{-} & \multirow{3}{*}{-} \\
\hline & Damietta & $173.95 \pm 0.90^{\mathrm{aA}}$ & $189.00 \pm 0.85^{\mathrm{aA}}$ & $173.64 \pm 0.76^{\mathrm{aA}}$ & & \\
\hline & Alexandria & $154.51 \pm 0.79^{\mathrm{aA}}$ & $165.75 \pm 0.82^{\mathrm{aA}}$ & $153.38 \pm 0.80^{\mathrm{aA}}$ & & \\
\hline
\end{tabular}

Table 4: Estimated daily intakes (EDI) and hazard ratio (HR) of toxic metals through consumption of shellfish from different studied areas

\begin{tabular}{clllllll}
\hline & \multirow{2}{*}{ Sampling sites } & \multicolumn{2}{c}{ Shrimp } & \multicolumn{2}{c}{ Oyster } & \multicolumn{2}{c}{ Crab } \\
\cline { 3 - 8 } & & EDI & HR & EDI & HR & EDI & HR \\
\hline \multirow{3}{*}{$\mathrm{Pb} \quad$ Ismailia } & 0.58 & 0.15 & 0.68 & 0.17 & 0.58 & 0.14 \\
& Damietta & 1.03 & 0.26 & 1.13 & 0.28 & 1.03 & 0.26 \\
& Alexandria & 0.85 & 0.21 & 0.93 & 0.23 & 0.86 & 0.22 \\
& Ismailia & 0.17 & 0.17 & 0.23 & 0.23 & 0.15 & 0.15 \\
$\mathrm{Hd}$ & Damietta & 0.30 & 0.30 & 0.38 & 0.38 & 0.25 & 0.25 \\
& Alexandria & 0.30 & 0.30 & 0.37 & 0.37 & 0.25 & 0.25 \\
& Ismailia & 0.56 & 1.87 & 0.68 & 2.27 & 0.56 & 1.86 \\
$\mathrm{As}$ & Damietta & 0.92 & 3.05 & 1.01 & 3.36 & 0.90 & 3.00 \\
& Alexandria & 0.79 & 2.64 & 0.86 & 2.87 & 0.79 & 2.64 \\
& Ismailia & 0.37 & 0.73 & 0.45 & 0.89 & 0.36 & 0.73 \\
$\mathrm{Hg}$ & Damietta & 0.66 & 1.33 & 0.80 & 1.60 & 0.66 & 1.33 \\
& Alexandria & 0.57 & 1.14 & 0.71 & 1.41 & 0.57 & 1.14 \\
\hline
\end{tabular}


Table 5: Estimated daily intakes (EDI) and hazard ratio (HR) of trace elements through consumption of shellfish from different studied areas

\begin{tabular}{|c|c|c|c|c|c|c|c|}
\hline & \multirow{2}{*}{ Sampling sites } & \multicolumn{2}{|c|}{ Shrimp } & \multicolumn{2}{|c|}{ Oyster } & \multicolumn{2}{|c|}{ Crab } \\
\hline & & EDI & HR & EDI & $\mathrm{HR}$ & EDI & $\mathrm{HR}$ \\
\hline \multirow{3}{*}{$\mathrm{Cu}$} & Ismailia & 0.78 & 0.003 & 1.69 & 0.01 & 1.29 & 0.004 \\
\hline & Damietta & 3.29 & 0.01 & 3.97 & 0.01 & 3.16 & 0.01 \\
\hline & Alexandria & 2.18 & 0.01 & 3.06 & 0.01 & 1.37 & 0.005 \\
\hline \multirow{3}{*}{$\mathrm{Cr}$} & Ismailia & 0.58 & 0.19 & 0.70 & 0.23 & 0.59 & 0.20 \\
\hline & Damietta & 0.82 & 0.27 & 0.95 & 0.32 & 0.81 & 0.27 \\
\hline & Alexandria & 0.67 & 0.22 & 0.82 & 0.27 & 0.73 & 0.24 \\
\hline \multirow{3}{*}{$\mathrm{Zn}$} & Ismailia & 7.80 & 0.03 & 9.25 & 0.03 & 8.13 & 0.03 \\
\hline & Damietta & 13.32 & 0.04 & 15.40 & 0.05 & 11.06 & 0.04 \\
\hline & Alexandria & 11.84 & 0.04 & 12.61 & 0.04 & 11.92 & 0.04 \\
\hline \multirow{3}{*}{$\mathrm{Ni}$} & Ismailia & 0.10 & 0.01 & 0.17 & 0.01 & 0.10 & 0.01 \\
\hline & Damietta & 0.36 & 0.02 & 0.50 & 0.02 & 0.90 & 0.04 \\
\hline & Alexandria & 0.30 & 0.01 & 0.38 & 0.02 & 0.31 & 0.02 \\
\hline \multirow{3}{*}{$\mathrm{Fe}$} & Ismailia & 23.93 & ND & 32.03 & ND & 24.21 & ND \\
\hline & Damietta & 120.70 & ND & 131.14 & ND & 120.48 & ND \\
\hline & Alexandria & 107.21 & ND & 115.00 & ND & 106.43 & ND \\
\hline
\end{tabular}

Table 6: Hazard index (HI) due to consumption of shellfish in different localities in Egypt

\begin{tabular}{lccc}
\hline & Shrimp & Oyster & Crab \\
\hline Ismailia & 3.15 & 3.84 & 3.12 \\
\hline Damietta & 5.28 & 6.02 & 5.2 \\
\hline Alexandria & 4.57 & 5.22 & 4.55 \\
\hline
\end{tabular}

concentration of $\mathrm{Cu}$ was found in oysters from Damietta; while the minimum value was found in shrimp from Ismailia. $\mathrm{Cu}$ concentrations in this study were comparable with those reported in fish from Alexandria, Egypt (31). On the other hand, the obtained results were higher than those detected in fish collected from Galas River and Beranang mining pool, Selangor $(0.01-0.05 \mu \mathrm{g} / \mathrm{g}$ ww) (43) and Palestine (0.25-0.91 $\mathrm{gg} / \mathrm{g} \mathrm{ww})$ (42). The $\mathrm{Cu}$ values observed in this study were lower than MPL (30 $\mu \mathrm{g} / \mathrm{g} w w)$ in fish as permitted by FAO (25).
The concentrations of $\mathrm{Cr}$ in shellfish were in the range of $0.84-1.37 \mu \mathrm{g} / \mathrm{g}$ ww with an an average concentration of $1.07 \mu \mathrm{g} / \mathrm{g}$ ww (Table 3).The highest value of $\mathrm{Cr}$ was detected in oysters from Damietta while the lowest value was observed in shrimp from Ismailia. The Cr levels in this study were nearly similar with those detected (0.1-1.10 $\mu \mathrm{g} / \mathrm{g} w w)$ in fish and shellfish from Calicut region, India (11). Although, lower concentrations were reported in (0.03-0.34 $\mu \mathrm{g} / \mathrm{g} \mathrm{ww})$ in fish from New Jersey (38).The observed values of $\mathrm{Cr}$ were below MPL for shellfish recommended by US FDA (24). 
The residual levels of $\mathrm{Zn}$ in shellfish were ranged from 11.25-22.19 $\mu \mathrm{g} / \mathrm{g}$ ww with a mean concentration of $16.22 \mu \mathrm{g} / \mathrm{g}$ ww (Table 3). The highest level of $\mathrm{Zn}$ was found in oysters from Damietta; meanwhile, the lowest level was detected in shrimp from Ismailia. The observed values of $\mathrm{Zn}$ in shellfish were nearly similar with those detected (16.53-22.12 $\mu \mathrm{g} / \mathrm{g} w \mathrm{w})$ in mussels from Alexandria, Egypt (31) and in investigated fish from Palestine (3.71-20.54 $\mu \mathrm{g} / \mathrm{g} w w)$ (32). However, higher levels (3.35- $41.87 \mu \mathrm{g} / \mathrm{g} w w)$ were reported in fish collected from El Menofiya Governorate, Egypt (44). Zn concentrations in this study were below MPL (40 $\mu \mathrm{g} / \mathrm{g} w w)$ in fish set by FAO (25).

The concentrations of $\mathrm{Ni}$ in shellfish was ranged between 0.15 and $1.30 \mu \mathrm{g} / \mathrm{g}$ ww with a mean concentration of $0.49 \mu \mathrm{g} / \mathrm{g}$ ww (Table 3 ). The highest levels were observed in shellfish from Damietta; whereas the lowest levels were detected in collected samples from Ismailia. $\mathrm{Ni}$ values observed in this study were comparable with those reported in blue crab from Mediterranean Lagoons (0.24-1.96 $\mu \mathrm{g} / \mathrm{g}$ ww) (45). However, Baharom and Ishak (43) cited that concentrations of $\mathrm{Ni}$ in fish from Galas River and Beranang mining pool, Selangor were lower $(0.06-0.07 \mu \mathrm{g} / \mathrm{g} w \mathrm{w})$ than those detected in this study. The levels of $\mathrm{Ni}$ detected in the present study were below MPL for shellfish adopted by US FDA (24).

Iron $(\mathrm{Fe})$ was the most abundant trace element in shellfish in this study. The maximum concentration of $\mathrm{Fe}$ was found in oysters from Damietta (189.00 $\mu \mathrm{g} / \mathrm{g} \mathrm{ww})$ and the minimum $\mathrm{Fe}$ concentration was detected in shrimp from Ismailia $(34.49 \mu \mathrm{g} / \mathrm{g} \mathrm{ww})$. The average value of $\mathrm{Fe}$ reported in this study was $125.14 \mu \mathrm{g} / \mathrm{g}$ ww (Table 3). The observed Fe values in shellfish were nearly similar with those detected in fish from El Menofiya Governorate, Egypt (34.97-165.30 $\mu \mathrm{g} / \mathrm{g}$ ww) (44) and in blue crab from Mediterranean Lagoons (25.50-170.00 $\mu \mathrm{g} / \mathrm{g} w w)$ (45). On the other hand, higher levels were reported in mussels from Alexandria, Egypt (261.16-332.15 $\mu \mathrm{g} / \mathrm{g} w \mathrm{w})$ (31). Fe levels in this study were higher than MPL in fish set by WHO/ FAO (46) (43 $\mu \mathrm{g} / \mathrm{g} w w)$ except Fe values in shrimp and crab from Ismailia.

\section{Daily intake and human risk assessment}

EDI of different heavy metals owing to consumption of shellfish in the three examined localities was evaluated in the present study as was found in Tables (4 and 5). It was clear that the highest EDI of the investigated heavy metals was found at Damietta especially due to oyster consumption. EDI values of $\mathrm{Pb}, \mathrm{Cd}$, As and $\mathrm{Hg}$ were $1.13,0.38,3.36$ and $1.60 \mu \mathrm{g} / \mathrm{Kg} /$ day, respectively; due to consumption of oyster at Damietta (Table 4). The highest recorded EDI values of different trace elements were similarly reported at Damietta due to oyster consumption (Table 5). The recorded EDI values in this study were strongly higher than that recorded at Catalonia, Spain (47). For instance, they reported that EDI values of $\mathrm{Pb}, \mathrm{Cd}, \mathrm{As}$ and $\mathrm{Hg}$ due to consumption of shellfish are 0.06, 0.04, 2.52 and $0.11 \mu \mathrm{g} / \mathrm{Kg} /$ day; respectively. Therefore, further investigation for the hazard ratio (HR) and hazard index (HI) is necessary due to shellfish consumption (Tables 4, 5 and 6). Values of HR and/or HI increasing than 1 indicate that there is a potential risk to human health.

$\mathrm{HR}$ exceeded 1 for both $\mathrm{As}$ and $\mathrm{Hg}$ in all examined shellfish species (Table 4). However, HI of different heavy metals exceeded 1 in all localities and in different shellfish (Table 6). In spite of having heavy metal load within the permissible limits, consumption of shellfish in these geographic areas may constitute a public health hazard. Thereby, some adverse effects such as hepatic and renal dysfunctions may be expected. Future approaches necessitate finding solutions to reduce the concentrations of heavy metals in the edible shellfish. Continuous monitoring studies are highly warranted to screen heavy metal load in fish and shellfish.

In Conclusion, this study confirmed that the residual levels of OCPs (HCB, heptachlor, heptachlor-epoxide, aldrin, endrin and $\gamma$ chlordane) were the predominant then followed by HCHs then DDTs. The highest concentrations of $\beta-\mathrm{HCH} \mathrm{HCH}$ and $\mathrm{p}, \mathrm{p}-\mathrm{DDE}$ in shellfish were attributed to their resistance nature for the microbial degradation, and thus the long half life. Of interest, oysters from Damietta showed the highest residual levels of OCPs and heavy metals among the analyzed shellfish species. The levels of OCPs and heavy metal residues were within the recommended level adopted by US FDA, FAO and EU except in few instances. From the analysis of EDI, HR and HI values for the metals in examined shellfish, it was declared that heavy metal load in shellfish must be reduced to decrease the 
possible toxicological complications arises from shellfish consumption.

\section{Acknowledgments}

The authors would like to thank the staff members at Central Agricultural Pesticides Laboratory, Agricultural Research Center, Doki, Egypt for their assistance in analysis of OCPs residues. Also, our deep gratefulness for the staff members at the Central Laboratory belonging to Faculty of Veterinary Medicine, Zagazig University for their helps and cooperation in heavy metal analysis.

\section{References}

1. Jones KC, de Voogt P. Persistent organic pollutants (POPs): state of the science. Environ Pollut 1999; 100: 209-21.

2. Iwata H, Tanabe S, Sakai N, Tatsukawa R. Distribution of persistent organochlorines in the oceanic air and surface seawater and the role of ocean on their global transport and fate. Environ Sci Technol 1993; 27: 1080-98.

3. Azab MM, Darwish AA, Mahmoud HA, Sdeek FA. Residue levels of organochlorine pesticides in some ecosystem components of Manzala Lake. Environ Monit Assess 2013; 185: 10257-68.

4. Mohamed AA, Tharwat AE, Khalifa HA. Estimation of organochlorine pesticides and heavy metal residues in two species of mostly consumed fish in Sharkia Governorate, Egypt. Jpn J Vet Res 2016; 64(Suppl 2): S233-41.

5. Tudor MI, Tudor M, David C, Teodorof L, Tudor $\mathrm{D}$, Ibram O. Heavy metals concentrations in aquatic environment and living organisms in the Danube delta, Romania. In: Simeonov L, Chirila $\mathrm{E}$, eds. Chemicals as intentional and accidental global environmental threats. Dordrecht: Springer, 2006: 435-42.

6. Papagiannis I, Kagalou I, Leonardos J, Petridis D, Kalfakakou V. Copper and zinc in four freshwater fish species from Lake Pamvotis (Greece). Environ Int 2004; 30: 357-62.

7. Tarras-Wahlberg NH, Flachier A, Lane SN, Sangfors O. Environmental impacts and metal exposure of aquatic ecosystems in rivers contaminated by small scale gold mining: the Puyango River basin, southern Ecuador. Sci Total Environ
2001; 278: 239-61.

8. Hogstrand C, Haux C. Binding and detoxification of heavy metals in lower vertebrates with reference to metallothionein. Comp Biochem Physiol C 1991; 100: 137-41.

9. Damek-Poprawa M, Sawicka-Kapusta K. Damage to the liver, kidney, and testis with reference to burden of heavy metals in yellow-necked mice from areas around steelworks and zinc smelters in Poland. Toxicology 2003; 186: 1-10.

10. Davodi M, Esmaili-Sari A, Bahramifarr N. Concentration of polychlorinated biphenyls and organochlorine pesticides in some edible fish species from the Shadegan Marshes (Iran). Ecotoxicol Environ Saf 2011; 74: 294-300.

11. Sankar TV, Zynudheen AA, Anandan R, Viswanathan Nair PG. Distribution of organochlorine pesticides and heavy metal residues in fish and shellfish from Calicut region, Kerala, India. Chemosphere 2006; 65: 583-90.

12. Otchere FA. Organochlorines (PCBs and pesticides) in the bivalves Anadara (Senilis) senilis, Crassostrea tulipa and Perna perna from the lagoons of Ghana. Sci Total Environ 2005; 348: 102-14.

13. Yohannes YB, Ikenaka Y, Nakayama SM, Saengtienchai A, Watanabe K, Ishizuka M. Organochlorine pesticides and heavy metals in fish from lake Awassa, Ethiopia: insights from stable isotope analysis. Chemosphere 2013; 91: 857-63.

14. Finerty MW, Madden JD, Feagley SE, Grodner RM. Effect of environs and seasonality on metal residues in tissues of wild and pond-raised crayfish in southern Louisiana. Arch Environ Contam Toxicol 1990; 19: 94-100.

15. IRIS. Integrated risk information system-database. Washington DC : US Environmental Protection Agency, 2007.

16. FAO. Nutrition country profiles - Egypt. Rome : FAO, 2003

17. Rainbow PS. Trace metal concentrations in aquatic invertebrates: why and so what? Environ Pollut 2002; 120: 497-507.

18. Zhou R, Zhu L, Kong Q. Levels and distribution of organochlorine pesticides in shellfish from Qiantang river, China. J Hazard Mater 2008; 152: 1192-200.

19. Khaled A, El Nemr A, Said TO, El-Sikaily A, Abd-Alla AM. Polychlorinated biphenyls and chlorinated pesticides in mussels from the Egyptian Red sea coast. Chemosphere 2004; 54: 1407-12.

20. Willett KL, Ulrich EM, Hites RA. Differential 
toxicity and environmental fates of hexachlorocyclohexane isomers. Environ Sci Technol 1998; 32: 2197-207.

21. Pandit GG, Mohan Rao AM, Jha SK, et al. Monitoring of organochlorine pesticide residues in the Indian marine environment. Chemosphere 2001; 44: 301-5.

22. Naso B, Perrone D, Ferrante MC, Bilancione M, Lucisano A. Persistent organic pollutants in edible marine species from the Gulf of Naples, Southern Italy. Sci Total Environ 2005; 343: 8395.

23. Perugini $\mathrm{M}$, Cavaliere $\mathrm{M}$, Giammarino A, Mazzone P, Olivieri V, Amorena M. Levels of polychlorinated biphenyls and organochlorine pesticides in some edible marine organisms from the Central Adriatic Sea. Chemosphere 2004; 57: 391-400.

24. US FDA. Fish and fisheries products hazards and controls guidance. 3rd ed. Silver Spring : Center for Food Safety and Applied Nutrition, 2001.

25. Nauen CE. Compilation of legal limits for hazardous substances in fish and fishery products. Rome : FAO, 1983: 5-100. FAO Fisheries Circular No. 764.

26. Commission Regulation of European Community (EC) No 396/2005 on maximum residue levels of pesticides in or on food and feed of plant and animal origin. Off J Eur Union L 2005; 48(70): 1-16. (16. 3. 2005)

27. Commission Regulation (EC) No. 178/2006 amending Regulation (EC) No 396/2005 on maximum residue levels of pesticides in or on food and feed of plant and animal origin. Off $\mathrm{J}$ Eur Union L 2006; 49(29): 3. (2. 2. 2006)

28. Commission Regulation (EC) No. 260/2008 amending Regulation (EC) No 396/2005 on maximum residue levels of pesticides in or on food and feed of plant and animal origin. Off $\mathrm{J}$ Eur Union $\mathrm{L}$ 2008; 51(76): 31. (19. 3. 2008)

29. Commission Regulation (EC) No. 299/2008 amending Regulation (EC) No 396/2005 on maximum residue levels of pesticides in or on food and feed of plant and animal origin. Off $\mathrm{J}$ Eur Union $\mathrm{L}$ 2008; 51(97). 67. (9. 4. 2008)

30. Tabari S, Saravi SSS, Bandany GA, Dehghan A, Shokrzadeh M. Heavy metals $(\mathrm{Zn}, \mathrm{Pb}, \mathrm{Cd}$ and $\mathrm{Cr}$ ) in fish, water and sediments sampled form Southern Caspian Sea, Iran. Toxicol Ind Health 2010; 26: 649-56.

31. Hussein A, Khaled A. Determination of metals in tuna species and bivalves from Alexandria, Egypt. Egypt J Aquat Res 2014; 40: 9-17.

32. Elnabris KJ, Muzyed SK, El-Ashgar NM. Heavy metal concentrations in some commercially important fishes and their contribution to heavy metals exposure in Palestinian people of Gaza Strip (Palestine). J Assn Arab Univ Basic Appl Sci 2013; 13: 44-51.

33. Commission Regulation (EC) No. 1881/2006 setting maximum levels for certain contaminants in foodstuffs. Off J Eur Union L 2006; 49(364): 5-24. (20. 12. 2006)

34. Yap CK, Ismail A, Tan SG. Heavy metal $(\mathrm{Cd}, \mathrm{Cu}, \mathrm{Pb}$ and $\mathrm{Zn})$ concentrations in the greenlipped mussel Perna viridis (Linnaeus) collected from some wild and aquacultural sites in the west coast of peninsular Malaysia. Food Chem 2004; 84: 569-75.

35. Morgan AM, Shin H-C, Abd El Aty AM. Characterization of the heavy metals contaminating the river Nile at El-Giza Governorate, Egypt and their relative bioaccumulations in Tilapia nilotica. Toxicol Res 2008; 24: 297-305.

36. IARC Working Group on the Evaluation of Carcinogenic Risks to Humans. Some drinking water disinfectants and contaminants, including arsenic. Monographs on chloramine, chloral and chloral hydrate, dichloroacetic acid, trichloroacetic acid and 3-chloro-4-(dichloromethyl)-5-hydroxy-2(5H)-furanone. IARC Monogr Eval Carcinog Risks Hum 2004; 84: 269-477.

37. Singh N, Kumar D, Lal K, Raisuddin S, Sahu AP. Adverse health effects due to arsenic exposure: modification by dietary supplementation of jaggery in mice. Toxicol Appl Pharmacol 2010; 242: 247-55.

38. Burger J, Gochfeld M. Heavy metals in commercial fish in New Jersey. Environ Res 2005; 99: 403-12.

39. Deshpande A, Bhendigeri S, Shirsekar T, Dhaware D, Khandekar RN. Analysis of heavy metals in marine fish from Mumbai Docks. Environ Monit Assess 2009; 159: 493-500.

40. Clarkson TW, Magos L. The toxicology of mercury and its chemical compounds. Crit Rev Toxicol 2006; 36: 609-62.

41. Velusamy A, Satheesh Kumar P, Ram A, Chinnadurai S. Bioaccumulation of heavy metals in commercially important marine fishes from Mumbai Harbor, India. Mar Pollut Bull 2014; 81: 218-24.

42. Commission Regulation of European Com- 
munity (EC) No. 466/2001 of 8 March 2001 setting maximum levels for certain contaminants in foodstuffs. Off J Eur Union L 2001; 44(77): 1.

43. Baharom ZS, Ishak, MY. Determination of heavy metal accumulation in fish species in Galas river, Kelantan and Beranang mining pool, Selangor. Procedia Environ Sci 2015; 30: 320-5.

44. Malhat F. Distribution of heavy metal residues in fish from the river Nile tributaries in Egypt. Bull Environ Contam Toxicol 2011; 87: 163-5.

45. Mutlu C, Turkmen M, Turkmen A, Tepe Y. Comparison of metal concentrations in tissues of blue crab, Callinectes sapidus from Mediterra- nean lagoons. Bull Environ Contam Toxicol 2011; 87: 282-6.

46. FAO/WHO. Joint FAO/WHO food standards programme codex committee on contaminants in foods. Fifth session. Rome : FAO; WHO, 2011: 64-89.

47. Llobet JM, Falco G, Casas C, Teixido A, Domingo JL. Concentrations of arsenic, cadmium, mercury, and lead in common foods and estimated daily intake by children, adolescents, adults, and seniors of Catalonia, Spain. J Agric Food Chem 2003; 51: 838-42.

\title{
RAVNI PREOSTANKOV ORGANOKLORINSKIH PESTICIDOV IN TEŽKIH KOVIN V LUPINARJIH IZ EGIPTA IN OCENA ZDRAVSTVENIH TVEGANJ
}

\author{
T.M. Saber, M.H.E. Khedr, W.S. Darwish
}

Povzetek: Vtej raziskavi smo proučevali ravni organokloriranih pesticidov (OCP) in ostankov težkih kovin v lupinarjih (kozice, ostrige in rakovice), zbranih iz treh egiptovskih provinc (Ismajlija, Damietta in Aleksandrija). Določene so bile vrednosti 12 OCP-jev, kot so heksaklorocikloheksani $(\mathrm{HCH})$, aldrin, endrin in diklorodifeniltrikloroetani (DDT). Prevladujoči odkriti OCP-ji so bili B-HCH, p,p-DDE in endrin. Vzorec kontaminacije OCP je bil vvrstnem redu drugih OCP-jev (HCB, heptaklor, heptaklor-epoksid, aldrin, endrin in $\gamma$ klordan) $>\mathrm{HCHs}>\mathrm{DDT}$. Ocenjeni so bili tudi ostanki nekaterih težkih kovin in elementov v sledovih. Največje preostale količine OCP-jev in težkih kovin so bile najdene v ostrigah, zbranih v provinci Damietta. Ocena tveganja za zdravje je bila določena z izračunom razmerja nevarnosti in indeksa nevarnosti. Koncentracije OCP-jev in težkih kovin v pregledanih školjkah so bile pod najvišjo stopnjo preostankov, ki so jo določile Združene države Amerike za prehrano in zdravila ter FAO. Zato bi bili lupinarji, proučeni v tej raziskavi, varni za prehrano ljudi.

Ključne besede: organoklorirani pesticidi; težke kovine; lupinarji; tveganje za zdravje; Egipt 